Vol.45, n. 4 : pp. 515-518, December 2002 ISSN 1516-8913 Printed in Brazil

\title{
Extraction Time for Soybean Isoflavone Determination
}

\author{
Mercedes C. Carrão-Panizzi ${ }^{1 *}$, Silvana Pedroso de Goés Favoni ${ }^{2}$ and Akio Kikuchi ${ }^{3}$ \\ ${ }^{1}$ Centro Nacional de Pesquisa da Soja - Embrapa Soja; C. P. 231; 86001-970; Londrina - PR - Brazil. ${ }^{2}$ Estagiária \\ Embrapa Soja. ${ }^{3}$ National Agricultural Research Center for Western Region; Kagawa - Japan
}

\begin{abstract}
Studies were carried out on the optimization of the extraction procedures for isoflavones determination in soybean by HPLC. Isoflavones were extracted from $100 \mathrm{mg}$ samples of full fat soybean flour "Kinako" (milled toasted grains). Recovery of average total isoflavones was higher when extraction was performed with agitation(217.2 $\mathrm{mg} / 100 \mathrm{~g})$, than without agitation $(191.0 \mathrm{mg} / 100 \mathrm{~g})$. Isoflavone extraction without agitation for 1,4, 20 and 24 hours, were equally efficient for total and individual compounds. These results suggested that an efficient isoflavone recovery could be achieved with extraction for one hour with agitation.
\end{abstract}

Key words: Soybeans, isoflavones, glucosides, aglucones, extraction, ethanol, HPLC

\section{INTRODUCTION}

Isoflavones are phenolic compounds used to prevent and treat of the chronic diseases (Barnes et al., 1999). Since isoflavones are present in soybean, they are becoming important components of the human diet. Several studies indicated variability for isoflavone content among soybean cultivars (Wang and Murphy, 1994a; Tsukamoto et al., 1995; Carrão-Panizzi et al., 1998), and within soybean food products, as a consequence of the different processing techniques (Wang and Murphy, 1994b; Coward et al., 1998).

In soybeans, isoflavones are found mostly as $\beta$ glucoside conjugate forms, which include, daidzin, genistin, glycitin and their malonil and acethil derivatives (Kudou et al., 1991). Isoflavone glucosides are hydrolised by the action of $\beta$ glucosidase, to the aglucone forms daidzein, genistein and glycitein (Matsuura et al., 1989). Soaking in water or fermentation are processing methodologies that enhance this hydrolysis (Coward et al., 1998).

Different methods are used for isoflavone determination although the High Performance Liquid Chromatography (HPLC) is the most common procedure, different research groups use different methodologies for isoflavone extraction. This includes solvents such as methanol (Coward et al., 1998) or ethanol, temperatures and length of time for extraction (Kudou et al.,1991; Kitamura et al., 1991; Tsukamoto et al., 1995). In the Breeding Laboratory of Embrapa's National Soybean Research Center, isoflavones are determined by using the methodology of Kudou et al. (1991), with some modifications. This work was carried out to define an optimum isoflavone extraction time with or without agitation. The shortest extraction time is important when a large number of samples are analysed, as is commom practice in breeding programs.

\footnotetext{
*Author for correspondence
} 


\section{MATERIALS AND METHODS}

Extraction: Isoflavones were extracted from 100 mg samples of full fat soybean flour Kinako (milled toasted grains). Samples were placed in test tubes with $4.0 \mathrm{ml}$ of $70 \%$ aqueous ethanol containing $0.1 \%$ acetic acid, at room temperature. The samples were extracted for different periods of times $(1,4,8,12,16,20$, and 24 hours), with and without constant agitation (shaker at $250 \mathrm{rpm}$ - Orbital Tecnal Mod. TE140). Each procedure was replicated two times. After extraction, $1.5 \mathrm{ml}$ of the extract was transferred to an "Eppendorff" tube and stored at $5{ }^{\circ} \mathrm{C}$.

HPLC Analysis: The samples were centrifuged for 10 minutes at $13.500 \mathrm{rpm}$ at $10^{\circ} \mathrm{C}$ temperature (Centrifuge Eppendorf mod. 5417R). After centrifugation, $100 \mu \mathrm{l}$ of the supernatant was transferred to an autosampler $(10 \mu \mathrm{l}$ was the volume injected). Isoflavone analysis were performed on ODS c-18 column (YMC-Pack ODS-AM), S-5 mm, 120 A (250 x 4.6 mm I.D.).
The mobile phase (solvent A) was a solution of acetonitrile and $0.1 \%$ acetic acid, while solvent $\mathrm{B}$ was a solution of water and $0.1 \%$ acetic acid. Initial gradient was $20 \%$ for the solvent $\mathrm{A}$ in the first 20 minutes, passing to $100 \%$ for 5 minutes and $20 \%$ for the last 15 minutes. The effluent was monitored at $260 \mathrm{~nm}$. The complete elution of each sample was performed in 40 minutes. Standard solutions daidzin, daidzein, genistin and genistein (SIGMA) were $0.0125 \mathrm{mg} / \mathrm{ml}$.

Statistical Analysis: Treatments were evaluated in a factorial experiment in a randomized complete design. Before testing treatments by ANOVA, the data were tested for normal distribution (Shapiro and Wilk, 1965), homogenety of variance (Hartley, 1940; Burr and Foster, 1972), and model additivity (Tukey, 1949). Differences among mean values were determined by using Tukey's test at $\mathrm{P} \leq 0.05$ (Cochran and Cox, 1957). Statistical Analysis System (SAS, 1995) was used to analyse the data.

Table 1 - Average ( \pm SD) concentration of total isoflavones $(\mathrm{mg} / 100 \mathrm{~g})$ in soybean flour (Kinako), extracted with and without agitation $(\mathrm{CV}=6.8 \%)^{1}$.

\begin{tabular}{cccc}
\hline Extraction time (hours) & Constant agitation & Without agitation & Mean \\
\hline 1 & $205.4 \mathrm{aA}( \pm 13.3)$ & $228.4 \mathrm{aA}( \pm 10.8)$ & $216.9 \mathrm{a}$ \\
4 & $218.2 \mathrm{aA}( \pm 6.2)$ & $198.9 \mathrm{abA}( \pm 11.6)$ & $208.9 \mathrm{ab}$ \\
8 & $223.0 \mathrm{aA}( \pm 1.3)$ & $164.6 \mathrm{bcB}( \pm 6.8)$ & $193.8 \mathrm{ab}$ \\
12 & $225.4 \mathrm{aA}( \pm 9.8)$ & $135.6 \mathrm{cB}( \pm 18.9)$ & $180.5 \mathrm{~b}$ \\
16 & $229.9 \mathrm{aA}( \pm 17.1)$ & $183.3 \mathrm{abB}( \pm 37.6)$ & $206.6 \mathrm{ab}$ \\
20 & $229.6 \mathrm{aA}( \pm 5.5)$ & $208.1 \mathrm{abA}( \pm 2.5)$ & $218.8 \mathrm{a}$ \\
24 & $189.0 \mathrm{aA}( \pm 4.9)$ & $218.7 \mathrm{aA}( \pm 7.7)$ & $203.6 \mathrm{ab}$ \\
\hline
\end{tabular}

${ }^{\mathrm{T}}$ Mean values followed by the same capital letter in the lines and the same small letter in the columns are not significantly different (Tukey $\mathrm{P} \leq 0.05$ ).

Table 2 - Average $( \pm \mathrm{SD})$ concentration of isoflavones compounds (mg/100g) in soybean flour (Kinako), extracted with agitation ${ }^{1}$.

\begin{tabular}{|c|c|c|c|c|c|c|}
\hline $\begin{array}{c}\text { Time } \\
\text { (hours) }\end{array}$ & Daidzin & Genistin & $\begin{array}{l}\text { Malonyl } \\
\text { Daidzin }\end{array}$ & $\begin{array}{l}\text { Malonyl } \\
\text { Genistin }\end{array}$ & Daidzein & Genistein \\
\hline 1 & $38.5 \mathrm{a}( \pm 0.95)$ & $61.1 \mathrm{a}( \pm 4.13)$ & $36.1 \mathrm{a}( \pm 3.35)$ & $59.6 \mathrm{a}( \pm 3.96)$ & $3.9 \mathrm{a}( \pm 0.21)$ & $6.2 \mathrm{a}( \pm 0.39)$ \\
\hline 4 & $38.4 \mathrm{a}( \pm 1.48)$ & $66.4 \mathrm{a}( \pm 1.53)$ & $38.3 \mathrm{a}( \pm 1.71)$ & $64.5 \mathrm{a}( \pm 1.76)$ & $4.1 \mathrm{a}( \pm 0.16)$ & $6.6 \mathrm{a}( \pm 0.15)$ \\
\hline 8 & $39.0 \mathrm{a}( \pm 0.72)$ & $67.6 \mathrm{a}( \pm 1.22)$ & $39.5 \mathrm{a}( \pm 1.61)$ & $65.9 \mathrm{a}( \pm 1.25)$ & $4.2 \mathrm{a}( \pm 0.10)$ & $6.7 \mathrm{a}( \pm 0.18)$ \\
\hline 12 & $39.0 \mathrm{a}( \pm 1.74)$ & $70.0 \mathrm{a}( \pm 2.73)$ & $37.3 \mathrm{a}( \pm 1.34)$ & 67.8 a $( \pm 2.59)$ & $4.2 \mathrm{a}( \pm 0.23)$ & $7.0 \mathrm{a}( \pm 0.32)$ \\
\hline 16 & $40.5 \mathrm{a}( \pm 4.23)$ & $70.6 \mathrm{a}( \pm 2.24)$ & 38.9 a $( \pm 4.72)$ & $68.6 \mathrm{a}( \pm 2.04)$ & $4.3 \mathrm{a}( \pm 0.26)$ & $7.0 \mathrm{a}( \pm 0.16)$ \\
\hline 20 & $40.7 \mathrm{a}( \pm 1.04)$ & $70.3 \mathrm{a}( \pm 1.52)$ & $39.3 \mathrm{a}( \pm 1.73)$ & $68.0 \mathrm{a}( \pm 1.49)$ & $4.5 \mathrm{a}( \pm 0.12)$ & $6.8 \mathrm{a}( \pm 0.14)$ \\
\hline 24 & $32.7 \mathrm{a}( \pm 1.05)$ & $58.2 \mathrm{a}( \pm 1.63)$ & $31.7 \mathrm{a}( \pm 0.92)$ & $56.4 \mathrm{a}( \pm 1.55)$ & $3.9 \mathrm{a}( \pm 0.21)$ & $6.1 \mathrm{a}( \pm 0.14)$ \\
\hline
\end{tabular}

${ }^{1}$ Mean values followed by the same letter in the columns are not significantly different (Tukey $\mathrm{P} \leq 0.05 ; \mathrm{CV}(\%)$ : daidzin $=7.5$; genistin $=6.7$; malonyl daidzin $=8.6$; malonyl genistin $=8.5$; daidzein $=7.0$; genistein $=6.8$ ) 


\section{RESULTS AND DISCUSSION}

Isoflavone extractions of the soybean flour under constant agitation were the same among the different extraction times for total isoflavone (Table 1), as well as for each isoflavone compound (Table 2). Isoflavone extraction without agitation for $1,4,20$ and 24 hours were equally efficient for total isoflavones and for the individual compounds (Tables 1 and 3).

Comparing both extraction conditions, there were some statistical differences for total isoflavones at 8 and 12 hours of extraction time (Table 1), with lower recovery of the isoflavones without agitation. The same tendency was observed for individual isoflavone compounds without agitation (Table 3). Looking at the concentrations of each isoflavone compounds, no differences in absolute values were observed in the extractions for one hour and 24 hours (Table 3). Comparing the average of total isoflavones recovery in the two extraction methodologies, data indicated higher isoflavone concentration when extraction was performed with agitation (217.2 $\mathrm{mg} / 100 \mathrm{~g})$. Without agitation conditions, average total isoflavone concentration was $191.0 \mathrm{mg} / 100 \mathrm{~g}$. These results suggested that an efficient isoflavone extraction could be achieved for one hour under constant agitation, as already observed by Kitamura et al. (1991) and Carrão-Panizzi et al. (1996). Cole and Cousin (1994) tested soybean isoflavone extraction with a solution of ethanol $80 \%$, under refluxe at room temperature. These authors suggested

that extraction at room temperature should be more efficient, because isoflavone malonyl forms were unstable in high temperatures, which promoted inter-conversion of the 6"O-malonylglucosides to the $\beta$-glucoside forms. Similar methodology was used by Carrão-Panizzi (1996), with an efficient recovery of isoflavones using extraction solution of ethanol $70 \%$, at constant agitation, at room temperature.

Kudou et al. (1991) extracted isoflavones with a solution of $70 \%$ ethanol for 24 hours at room temperature and for 15 hours at $80{ }^{\circ} \mathrm{C}$. In the extraction at room temperature, manolylated isoflavone glucosides were the

major constituents. When the extraction was carried out at $80^{\circ} \mathrm{C}$, lower concentrations of these compounds were observed. Tsukamoto et al. (1995) used the same method of Kudou et al. (1991), extracting isoflavones from whole seeds and embrionic axis for 24 hours.

Table 3 - Average ( \pm SD) concentration of isoflavone compounds (mg/100g) in soybean flour (Kinako), extracted without agitation ${ }^{1}$.

\begin{tabular}{|c|c|c|c|c|c|c|}
\hline $\begin{array}{c}\text { Time } \\
\text { (hours) }\end{array}$ & Daidzin & Genistin & $\begin{array}{l}\text { Malonyl } \\
\text { Daidzin }\end{array}$ & $\begin{array}{l}\text { Malonyl } \\
\text { Genistin }\end{array}$ & Daidzein & Genistein \\
\hline 1 & $39.7 \mathrm{a}( \pm 2.41)$ & $69.1 \mathrm{a}( \pm 1.36)$ & $39.9 \mathrm{a}( \pm 2.31)$ & $66.7 \mathrm{a}( \pm 1.24)$ & $4.3 \mathrm{ab}( \pm 0.36)$ & $6.9 \mathrm{a}( \pm 0.15)$ \\
\hline 4 & $32.7 \mathrm{ab}( \pm 1.07)$ & $61.4 \mathrm{ab}( \pm 3.89)$ & $35.1 \mathrm{ab}( \pm 2.60)$ & $\begin{array}{c}59.5 \mathrm{ab} \\
( \pm 3.57)\end{array}$ & $3.9 \mathrm{ab}( \pm 0.29)$ & $6.2 \mathrm{ab}( \pm 0.35)$ \\
\hline 8 & $28.3 \mathrm{bc}( \pm 1.03)$ & $51.3 \mathrm{bc}( \pm 1.33)$ & $27.8 \mathrm{bc}( \pm 1.11)$ & $\begin{array}{l}50.1 \text { bc } \\
( \pm 1.20)\end{array}$ & $3.3 \mathrm{bc}( \pm 0.08)$ & $5.3 \mathrm{bc}( \pm 0.08)$ \\
\hline 12 & $22.8 \mathrm{c}( \pm 2.59)$ & $42.0 \mathrm{c}( \pm 4.63)$ & $22.3 \mathrm{c}( \pm 2.88)$ & $41.2 \mathrm{c}( \pm 4.65)$ & $2.7 \mathrm{c}( \pm 0.37)$ & 4.5 c $( \pm 0.49)$ \\
\hline 16 & $\begin{array}{c}31.8 \mathrm{abc} \\
( \pm 5.54)\end{array}$ & $\begin{array}{c}56.3 \mathrm{abc} \\
( \pm 9.69)\end{array}$ & $\begin{array}{c}31.0 \mathrm{abc} \\
( \pm 4.90)\end{array}$ & $\begin{array}{c}55.0 \mathrm{abc} \\
( \pm 9.28)\end{array}$ & $3.6 \mathrm{abc}( \pm 0.60)$ & $5.7 \mathrm{abc}( \pm 0.95)$ \\
\hline 20 & $35.9 \mathrm{ab}( \pm 0.82)$ & $63.7 \mathrm{ab}( \pm 1.50)$ & $36.1 \mathrm{ab}( \pm 0.73)$ & $62.1 \mathrm{ab}( \pm 1.27)$ & $3.9 \mathrm{ab}( \pm 0.22)$ & $6.3 \mathrm{ab}( \pm 0.22)$ \\
\hline 24 & $37.6 \mathrm{a}( \pm 0.92)$ & $66.8 \mathrm{a}( \pm 2.45)$ & $37.2 \mathrm{ab}( \pm 0.91)$ & $65.2 \mathrm{a}( \pm 2.11)$ & $4.5 \mathrm{a}( \pm 0.60)$ & 6.9 a $( \pm 0.54)$ \\
\hline
\end{tabular}

${ }^{1}$ Mean values followed by the same letter in the columns are not significantly different (Tukey $\mathrm{P} \leq 0.05 ; \mathrm{CV}(\%)$ : daidzin $=7.5$; genistin $=6.7$; malonyl daidzin $=8.6$; malonyl genistin $=8.5$; daidzein $=7.0 ;$ genistein $=6.8$ ).

According to the results, isoflavone extraction from soybean flours could be efficiently achieved by using ethanol $70 \%$ as solvent for one hour with agitation at room temperature. The constant shake allow better contact among the soybean particules and the solution. Extraction for 24 hours without agitation was also efficient. However, when a large number of samples have to be analysed, analysis proceedures that include extractions for one hour, are an important factor to save time. 


\section{ACKNOWLEDGEMENT}

We thank Dr. José Erivaldo for help with the statistical analysis. This paper was approved for publication by the Head of Research and Development of Embrapa Soybean as manuscript number 07/2001.

\section{RESUMO}

A soja apresenta isoflavonas que são compostos relacionados com a saúde humana. A otimização dos procedimentos de extração para determinação de isoflavonas por HPLC, são importantes quando muitas amostras são analisadas. As isoflavonas foram extraídas a partir de $100 \mathrm{mg}$ de amostras de farinha integral de soja (Kinako) (grãos tostados e moídos), com solução aquosa etanol (70\%), adicionado de $0,1 \%$ de ácido acético, à temperatura ambiente, por $1,4,8,12,16,20$, e 24 horas, com e sem agitação constante. A recuperação das isoflavonas totais médias foi mais alta quando a extração foi conduzida sob agitação $(217.2 \mathrm{mg} / 100 \mathrm{~g})$ do sem agitação $(191 \mathrm{mg} / 100 \mathrm{~g})$. A extração de isoflavonas por 1, 4, 20 e 24 horas, sem agitação, foi igualmente eficiente para o total de isoflavonas e para os compostos individualmente. Com agitação constante, não houve differenças na recuperação de isoflavonas para todas as condições de extração. Estes resultados sugerem que uma recuperação eficiente de isoflavonas pode ser obtida quando a extração é realizada por uma hora e sob agitação constante.

\section{REFERENCES}

Barnes, S., Kim, H. and Xu, J. (1999), Soy in the prevention and treatment of chronic diseases. Paper presented at Congresso Brasileiro de Soja. Londrina. Anais ... Londrina-Embrapa. pp. 295-308.

Burr, I. W. and Foster, L. A. (1972), A test for equality of variances. West Lafayette, University of Purdue. (Mimeo series, 282). pp. 26.

Cochran, W. G. and Cox, G. M. (1957), Experimental designs. New York : John Willey. pp. 611.

Carrão-Panizzi, M. C. (1996), Isoflavo-nóides em soja (Glycine max (L.) Merrill): Variabilidade genética e ambiental de cultivares e efeitos no processamento de extrato solúvel de soja. Tese Doutorado em Ciência de Alimentos, Departamento de Tecnologia de Alimentos, Universidade Estadual de Londrina. Londrina, Brasil. pp. 122.
Carrão-Panizzi, M. C.; Kitamura, K.; Beléia, A. D. P. and Oliveira, M. C. N. (1998), Influence of growth locations on isoflavone contents in Brazilian soybean cultivars. Breeding Science, 48, 409-413.

Cole, K. D. and Cousin Jr., S. L. (1994), Size exclusion chromatography of soybean proteins and isoflavones. Journal of Agriculture and Food Chemistry, 42, 2713-2720.

Coward, L.; Smith, M.; Kirk, M. and Barnes, S. (1998), Chemical modification of isoflavones in soyfoods during cooking and processing. American Journal Clinical Nutrition, 68 : (Suppl. 6), 1486S-1491S.

Hartley, H. O. (1940), Testing the homogeneity of a set of variances. Biometrika, 31, 249-255.

Kitamura, K.; Igita, K.; Kikuchi, K.; Kudou, S. and Okubo, K. (1991), Low isoflavone content in early maturing cultivars, so called summer-type soybeans. (Glycine max (L.) Merril). Japanese Journal of Breeding, 4151-654.

Kudou, S.; Fleury, Y.; Welti, D.; Magnolato, D.; Uchida, T.; Kitamura, K. and Okubo, K. (1991), Malonil isoflavone glycosides in soybeans seeds (Glycine max Merrill). Agriculture Biology Chemistry, 55, 2227-2233.

Matsuura, M.; Obata, A. and Fukushima, D. (1989), Objectionable flavor of soymilk developed during the soaking of soybeans and its control. Journal of Food Science, 5,4602-605.

SAS Institute (1995), SAS proprietary software release 6.09. Cary, NC.

Shapiro, S. S. and Wilk, M. B. (1965), An analysis of variance test for normality. Biometrika, 52, 591-611.

Tsukamoto, C.; Shimada, S.; Igita, K.; Kudou, S.; Kokubun, M.; Okubo, K. and Kitamura, K. (1995), Factors affecting isoflavones content in soybean seeds: changes in isoflavones, saponins and composition of fatty acids at different temperatures during seed development. Journal of Agriculture and Food Chemistry, 43, 1184-1192.

Tukey, J. W. (1949), One degree of freedom for nonadditivity. Biometrics, 5, 232-242.

Wang, H. and Murphy, P. (1994a), Isoflavone composition of American and Japanese soybeans in Iowa : Effects of variety, crop year, and location. Journal of Agriculture and Food Chemistry, 42, 674-1677.

Wang, H. and Murphy, P. (1994b), Isoflavone content in commercial soybean foods Journal of Agriculture and Food Chemistry, 42, 1666-1673.

Received: April 25, 2001; Revised: September 25, 2001; Accepted: January 18, 2002. 